\title{
EL SACRIFICIO DE ISAAC DE JERÓNIMO JACINTO DE ESPINOSA, MODELO DEL ARTE RELIGIOSO CONTRARREFORMISTA VALENCIANO*
}

\author{
EL SACRIFICIO DE ISAAC BY JERÓNIMO JACINTO \\ DE ESPINOSA, A MODEL OF VALENCIAN \\ COUNTER-REFORMATION RELIGIOUS ART
}

\author{
ANDRÉS HERRAIZ LLAVADOR \\ (Universitat de València) \\ https://orcid.org/0000-0002-4728-1095
}

Resumen: El presente artículo aborda el estudio del lienzo El Sacrificio de Isaac de Jerónimo Jacinto de Espinosa (ca. 1640), que actualmente se encuentra en la Real Parroquia de San Andrés de Valencia. Desde una perspectiva culturalista, analiza la concreción de la configuración icónica a partir de la tradición cultural convencionalizada en su vertiente tanto visual como escrita. Su principal propósito es poner de relieve la obra del artista alicantino realizando un análisis iconográfico-iconológico que permita acceder a la función que la misma tuvo en el contexto cultural del siglo XVII valenciano.

Palabras clave: Sacrificio de Isaac, Jerónimo Jacinto de Espinosa, Barroco, Contrarreforma, Iconografía-Iconología, Pintura valenciana.

\footnotetext{
* El presente trabajo forma parte del proyecto de $\mathrm{I}+\mathrm{D}+\mathrm{i}$ «Los tipos iconográficos de la tradición cristiana» PID2019-110457GB-I00, del Ministerio de Ciencia e Innovación, dirigido por Rafael García Mahíques y Sergi Doménech García (Universitat de València) y se ha realizado gracias a la financiación de la Universitat de València y su programa de ayudas «Atracció de talent».
} 
AbSTRACT: This article deals with the study of the canvas El sacrificio de Isaac by Jerónimo Jacinto de Espinosa (ca. 1640), which is currently in the Royal Parish of San Andrés in Valencia. From a culturalist perspective, it analyzes the concretion of the iconic configuration from the conventionalized cultural tradition in both its visual and written aspects. Its main purpose is to highlight the work of the Alicante artist by carrying out an iconographic analysis that allows access to the function that it had in the cultural context of the Valencian seventeenth century.

Key words: Binding of Isaac, Jerónimo Jacinto de Espinosa, Baroque, Counter-Reformation, Iconography-Iconology, Valencian Painting.

La historia del arte ha dedicado numerosos estudios a la obra de Jerónimo Jacinto de Espinosa, no obstante, ninguno de estos se ha detenido a analizar desde una perspectiva culturalista el lienzo conocido como El Sacrificio de Isaac (ca. 1640), actualmente en la Real Parroquia de San Andrés de Valencia. El presente estudio tiene como objetivo poner de relieve la obra del artista contestano tomando como punto de partida las lecturas que autores como Pérez Sánchez, Fernando Benito, Rafael García Mahíques o Asunción Alejos Morán realizaron de la producción pictórica del pintor y su tiempo. De este modo, el análisis iconográfico-iconológico del Sacrificio de Isaac de Espinosa nos permite acceder a la función que esta obra tuvo en el contexto cultural del siglo XviI valenciano y, a su vez, subsanar la orfandad académica a la que este lienzo ha sido relegado. En primer lugar, se ha atendido a los aspectos documentales relativos tanto a la obra como al artista. En segundo lugar, se ha puesto en relación el tipo iconográfico con la tradición cultural convencionalizada, realizando un análisis comparativo entre los lienzos de Espinosa y Orrente. Así mismo, se ha llevado a cabo un análisis pormenorizado de los elementos presentes en la configuración icónica y han sido abordadas las fuentes icónicas y textuales que llevaron a Espinosa a configurar una versión única del pasaje veterotestamentario. Finalmente, el estudio atiende a la función que la obra y su compañera Abraham y Melquisedec, atribuida también a Espinosa, tuvieron en el contexto contrarreformista valenciano, integrándose dentro de un programa iconográfico destinado al culto eucarístico.

El Sacrificio de Isaac y su pareja Abraham y Melquisedec flanquean el altar mayor de la Real Parroquia de San Andrés de Valencia. El edificio, actualmente situado en la calle de Colón, fue construido con el fin de dar acogida al culto del santo en un nuevo emplazamiento, tras quedar inutilizada la antigua sede. La anterior ubicación, localizada sobre una pretérita mezquita, era la de una de las iglesias más antiguas de Valencia, reconstruida a principio del siglo XVII 
bajo el mandato del Patriarca Ribera. ${ }^{1}$ Será en 1946 cuando se tome la decisión de trasladar el lugar de advocación del santo y toda la colección de obras maestras del anterior emplazamiento, hoy iglesia de San Juan de la Cruz, a la actual Parroquia de San Andrés, encargando al arquitecto diocesano Vicente Traver la realización del templo actual, concluido en 1953.

Poco se conoce sobre la procedencia de los lienzos El Sacrificio de Isaac [fig.1] y Abrahán y Melquisedec [fig.2] realizados por Espinosa ca. 1640 y presentados en 1972 de la mano de Pérez Sánchez, quien los ubicó en la producción central del artista. ${ }^{2}$ Ambas obras han sido abordadas en contadas ocasiones por estudios monográficos y catálogos dedicados a su producción artística. En este sentido, la ausencia de noticias documentales señalada tanto por Adela Espinós ${ }^{3}$ como por Victoria Bosch ${ }^{4}$ podría justificar la poca atención prestada por parte de los estudios previos.

Por lo que respecta a la biografía del artista, sabemos por la fe de bautismo citada por Orellana ${ }^{5}$ que Jerónimo Jacinto de Espinosa nació en Cocentaina el 20 de julio de 1600 trasladándose a Valencia antes de 1623, probablemente en 1616, cuando ingresó en el colegio de pintores de la ciudad, tal como apuntó Luis Tramoyeres a principios del siglo xx. ${ }^{6}$ Espinosa se formó en la capital del Turia, tal y como señalaba Palomino, en el taller de Francisco Ribalta encontrando en la producción pictórica de ambos numerosas similitudes estilísticas y compositivas. ${ }^{7}$ Siguiendo lo descrito por Orellana, sabemos que casó joven y enviudó pronto. ${ }^{8}$ En 1631 bautizó a su hijo Jacinto Raymundo Feliciano en la antigua iglesia de San Andrés. ${ }^{9}$ Tras la desaparición del taller de los Ribalta, tal como advertía Fernando Benito, la fama de Espinosa creció y, siguiendo la estela que estos habrían dejado, el artista continuó realizando obras de carácter religioso a las que imbuía su estilo propio, formando parte de la gran generación artística que protagonizó las mejores obras de la pintura española del siglo de Oro. ${ }^{10}$

1. Fernando Pingarrón-Esaín Seco: Arquitectura Religiosa del siglo xviI en la ciudad de Valencia, Valencia: Ayuntamiento de Valencia, 1998, pp. 142-161.

2. Alfonso E. PÉrez SÁnchez: Jerónimo Jacinto de Espinosa, Madrid: Instituto Diego Velázquez, 1972, p. 31.

3. Adela Espinós DíAz: Dibuixos Valencians del segle xVII, Valencia: Conselleria de Cultura, 1994, pp. 84-85.

4. Victoria Bosch Moreno: «Jerónimo Jacinto de Espinosa, Concepción Niña», en Pablo González Tornell (ed): Intacta María. Política de religiosidad en la España barroca, Valencia: Generalitat Valenciana, 2020, pp. 276-280.

5. Marcos A. de Orellana, ed. Xavier de Salas: Biografía pictórica Valentina, Valencia: Ayuntamiento de Valencia, 1967, p.138.

6. Luis Tramoyeres Blasco: «Un Colegio de Pintores en Valencia», Archivo de Investigaciones Históricas, I, 1911, p.520.

7. Antonio Palomino De Castro y Velasco: El Museo Pictórico, Madrid: Aguilar, 1947, p. 1006.

8. Marcos A. de Orellana: Biografía pictórica valentina, Xavier de Salas (ed.), Valencia: Ayuntamiento de Valencia, 1967, p.141.

9. Luis Tramoyeres Blasco: «El pintor Jerónimo Jacinto de Espinosa», Archivo de Arte Valenciano, 1915, 1, pp. 127-141.

10. Fernando Benito Doménech: «La pintura durant els segles xvi i xviI», en Enrique A. Llobregat i José Francisco Ivars (dir.), Història de l'Art al País Valencià, Valencia: Biblioteca d'estudis i investigacions Tres i Quatre, 1988, pp. 61-103. 


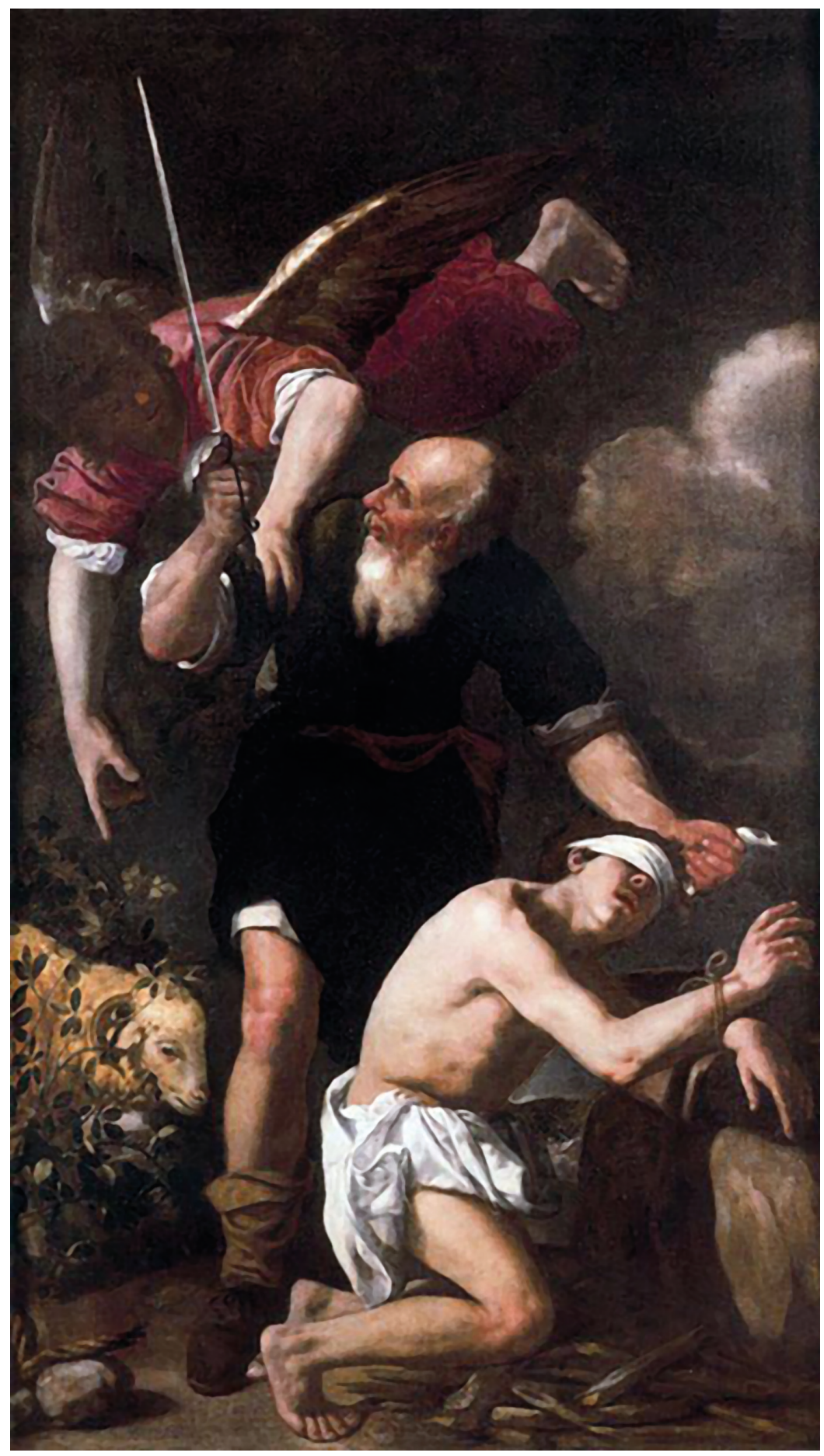

Fig. 1. Jerónimo Jacinto de Espinosa, Sacrificio de Isaac, ca.1640, 100 x 35 cm, Real Parroquia de San Andrés, Valencia 


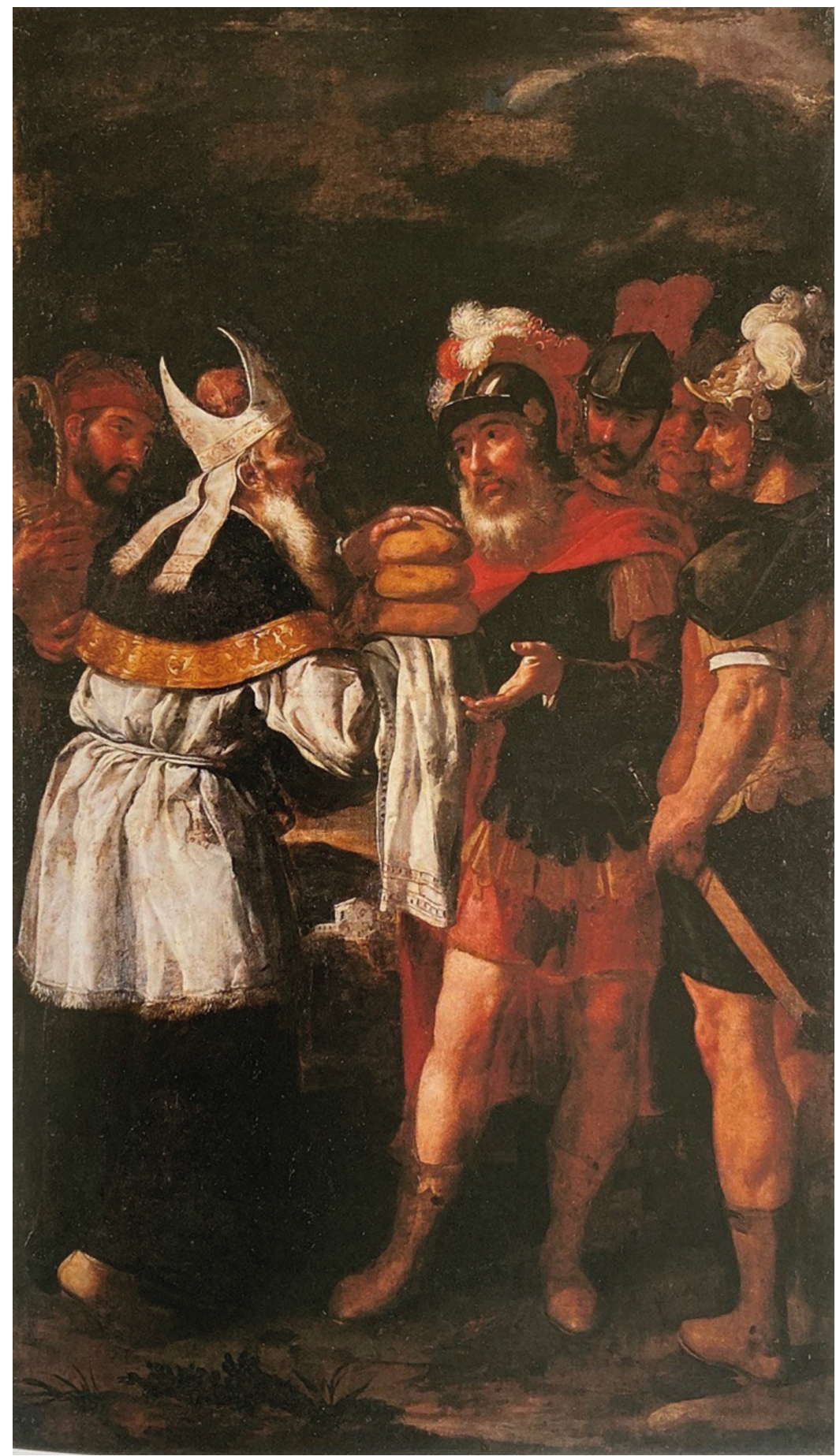

Fig. 2. Jerónimo Jacinto de Espinosa, Abrahán y Melquisedec, ca.1640, Real Parroquia de San Andrés, Valencia 
El análisis estilístico de la producción pictórica de Espinosa y, más concretamente del Sacrificio de Isaac, confirma lo ya establecido por otros autores cuyos estudios se centraron en la relación de la pincelada de Espinosa y la de Ribalta. Las tonalidades terrosas o la configuración de las figuras angélicas de La visión de la Storta, obra estudiada en profundidad por Rafael García Mahíques, ${ }^{11}$ permitieron a autores como Fernando Benito aseverar la impronta ribaltiana en la obra del joven Espinosa. ${ }^{12}$ Mas allá de su temprana formación en el taller de los Ribalta, contamos con pocas referencias documentales sobre el aprendizaje del artista contestano. Si bien sabemos que conocería la obra de los artistas italianos, hemos de poner en duda, como ya hizo Orellana, su posible formación en Italia, pues la ingente cantidad de obras realizadas en ámbito valenciano, así como diversos aspectos de su vida privada, poco tiempo pudieron dejarle para realizar tal formación. Se trata, por tanto, de un artista que «admiró el orbe, sin tal vez haber viajado más que de Cosentayna a Valencia». ${ }^{13}$ Por otro lado, las similitudes formales entre la producción pictórica de Espinosa y la obra de Zurbarán llevaron a Fernando Benito a advertir un posible viaje a Sevilla en el cual estaría en contacto con la obra del artista de Fuente de Cantos. ${ }^{14}$

Todas estas influencias de carácter estilístico devienen en relaciones compositivas en el momento en que artistas como Alonso Cano, Tomás Hernández, Isidoro Tapies, o Pedro de Orrente [fig.3] albergan en su producción pictórica lienzos con el mismo tipo iconográfico. Los artistas formados en la escuela sevillana, como Alonso Cano o Juan de Valdés Leal, dieron primacía a las composiciones de carácter horizontal en las que la intervención angélica cobra un papel protagonista, presentando a un Isaac maniatado por la espalda, con los ojos vendados y dispuesto sobre un altar conformado por lajas pétreas y leños. Tanto en el caso de Tomás Hernández como en el de Isidoro Tapies, si bien el altar presenta la misma disposición, Isaac ha sido dispuesto sobre este con las manos atadas por el frente, sin presentar venda sobre sus ojos, apartando la vista del Ángel de Yahvé que detiene el brazo ejecutor de Abrahán.

11. Rafael García Mahíques: «Jerónimo Jacinto de Espinosa y la iconografía de San Ignacio de Loyola en la Casa Profesa de Valencia», Archivo español de Arte, 68, 1995, pp. 271-283.

12. Fernando Benito Domenech: «Jerónimo Jacinto de Espinosa en sus comienzos como pintor», Ars Longa, 4, 1993, pp.59-63.

13. Marcos A. de Orellana: Biografía pictórica valentina, Xavier de Salas (ed.), Valencia: Ayuntamiento de Valencia, 1967p. 143.

14. Fernando Benito Doménech: Los Ribalta y la pintura valenciana de su tiempo, Valencia: Diputación Provincial de Valencia, 1987, p. 280. 


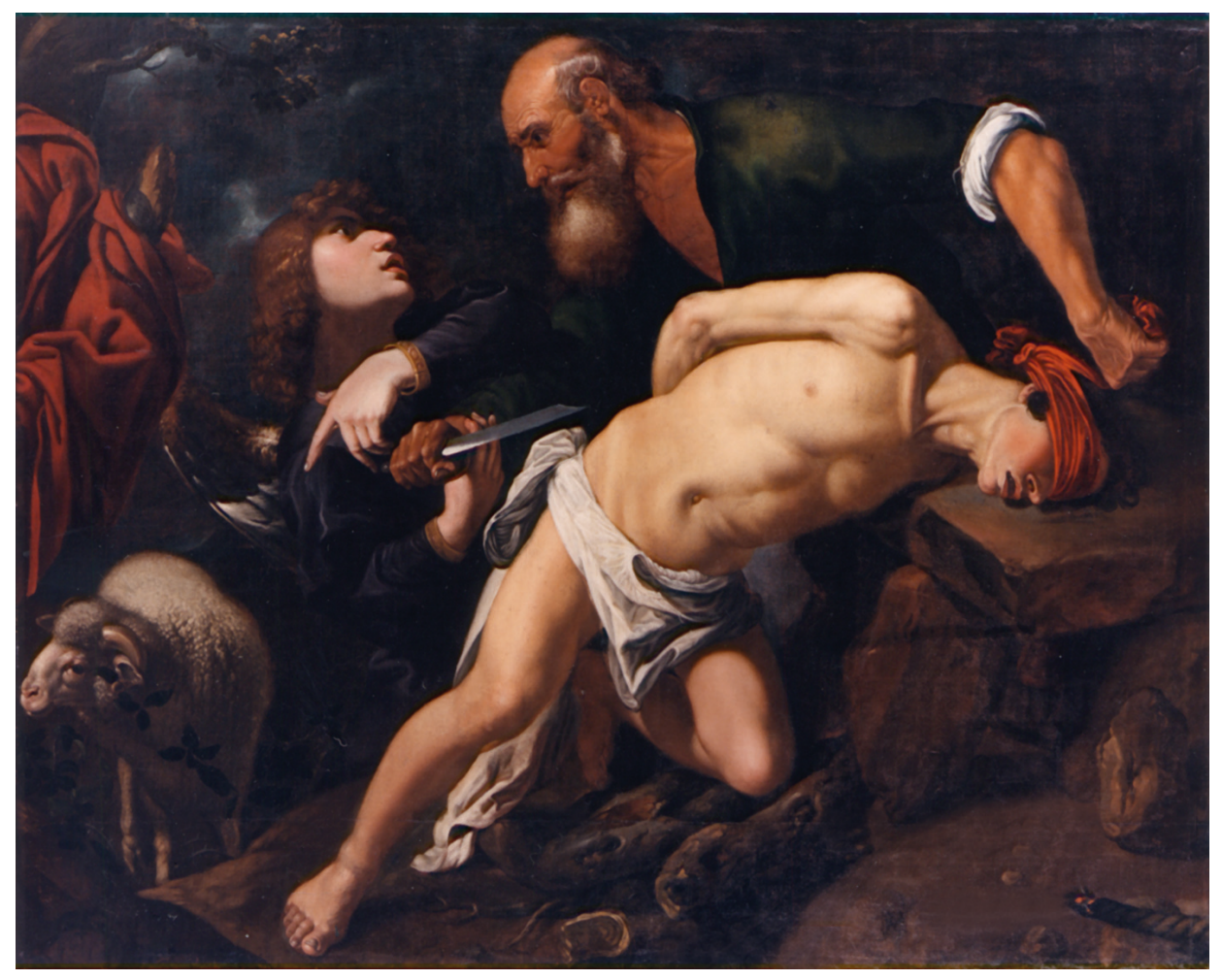

Fig. 3. Pedro de Orrente, Sacrificio de Isaac, ca. 1616, 133,5 x 167 cm Museo de Bellas Artes, Bilbao

Finalmente, y aproximándonos al ámbito más cercano a Espinosa, el análisis comparativo del Sacrificio de Isaac pintado por Pedro de Orrente y el realizado por Espinosa evidencia las innovaciones que, a modo de variante tipológica, recogió el artista contestano en su lienzo para la Parroquia de San Andrés de Valencia. Pedro de Orrente, al igual que Espinosa, configura la imagen de un Abrahán anciano, tal y como se presenta en las Sagradas Escrituras, poniendo ambos de relieve este hecho a través de la calvicie del patriarca. Esta característica fisonómica configura una particularidad icónica poco común dentro de la continuidad del tipo iconográfico, encontrando escasos ejemplos previos a Espinosa, como es el caso de las puertas de bronce de la Catedral de Monreale (ca. 1185, Bonanno Pisano, Pisa, Catedral de Monreale).

Por lo que respecta al significado fáctico y expresivo, siguiendo la terminología panofskiana, reconocemos en la gestualidad de Abrahán la virulencia necesaria para cometer el sacrificio. Esta se manifiesta a través de la tela que cubre los ojos de Isaac y de la cual se vale el padre para aferrarse a 
su hijo con el fin de ejecutarlo. En la línea de lo definido por Aby Warburg, esta fórmula emotiva o Pathosformeln proviene de la Antigüedad y evidencia los extremos de un lenguaje gestual patente en la retórica muscular tanto del patriarca como de Isaac. Con todo ello, las cualidades significantes que subyacen en este esquema compositivo permiten a Abrahán erigirse como un héroe de la fe católica. ${ }^{15}$

En ambos casos el carnero, que habrá de sustituir a Isaac y que constituirá el sacrificio final, se encuentra atrapado en un zarzal. La similitud de la figura angélica ubicada en el cuadro de Orrente junto a las ropas de Isaac, con el ángel del lienzo de Tobias y el Ángel de Espinosa, advierte las similitudes estilísticas entre ambos artistas que, durante años, han conducido la opinión de algunos académicos hacia la confusión en cuestiones de atribución. Estas semejanzas, unidas al claroscuro que invade toda la composición, evidencian la deuda orrentiana en el lienzo de Espinosa, tal y como apunta David Gimilio. ${ }^{16}$ Con todo ello, los lienzos de Cano, Hernández, Tapies u Orrrente atestiguan como el Génesis 22 ha sido representado a lo largo de los siglos, hallando en la literatura patrística y en la tratadística barroca las claves para su interpretación.

A la hora de acometer un análisis pormenorizado del Sacrificio de Isaac de Espinosa, hemos de partir, en primer lugar, de la fuente directa hallada en la propia descripción del pasaje veterotestamentario (Gn 22, 1-18): ${ }^{17}$

15. Andrés Herraiz Llavador: «Abraham como héroe cristiano. A propósito del lienzo "El sacrificio de Isaac" de Espinosa», en María de los Ángeles Fernández Valle (ed. lit.), Carme López Calderón (ed. lit.), Inmaculada Rodríguez Moya (ed. lit.), Discursos e imágenes del barroco iberoamericano, Sevilla: Andavira, 2019, pp. 101-116.

16. David Gimilio Sanz: «Jerónimo Jacinto de Espinosa (1600-1667), un pintor valenciano en el Siglo de Oro español», en Pablo González Tornel (ed.), La Inmaculada Concepción de Valencia (1662). Conocer el pasado, recuperar la memoria, Gijón: Ediciones Trea, 2020, p.65-89.

17. «Quae postquam gesta sunt, tentavit Deus Abraham et di xit ad eum: 'Abraham'. Ille respondit: 'Adsum'. Ait: 'Tolle filium tuum unigenitum, quem diligis, Isaac et vade in terram Moria; atque offer eum ibi in holocaustum super unum montium, quem monstravero tibi'. 3 Igitur Abraham de nocte consurgens stravit asinum suum ducens secum duos iu- venes suos et Isaac filium suum. Cumque concidisset ligna in holocaustum, surrexit et abiit ad locum, quem praeceperat ei Deus. Die autem tertio, elevatis oculis, vidit locum procul dixitque ad pueros suos: 'Exspectate hic cum asino. Ego et puer illuc usque prope- rantes, postquam adoraverimus, revertemur ad vos'. Tulit quoque ligna holocausti et imposuit super Isaac filium suum; ipse vero por- tabat in manibus ignem et cultrum. Cumque duo pergerent simul, dixit Isaac Abrahae patri suo: 'Pater mi'. Ille respondit: 'Quid vis, fili?' 'Ecce, in- quit, ignis et ligna; ubi est victima holocausti?'. Dixit Abraham: 'Deus providebit sibi victimam holocausti, fili mi.' Pergebant ambo pariter; et venerunt ad locum, quem ostenderat ei Deus, in quo aedificavit Abraham altare et desuper ligna composuit. Cumque colligasset Isaac filium suum, posuit eum in altari super struem lignorum extenditque Abraham manum et arripuit cultrum, ut immolaret filium suum. Et ecce angelus Domini de caelo clamavit: 'Abraham, Abraham'. Qui respondit: 'Adsum'. Dixitque: 'Non extendas manum tuam super puerum neque facias illi quidquam. Nunc cognovi quod times Deum et non pepercisti filio tuo unigenito propter me'. Levavit Abraham oculos suos viditque arietem unum inter vepres haerentem cor- nibus; quem assumens obtulit holocaustum pro filio. Appellavitque nomen loci illius: 'Dominus videt'. Unde usque hodie dicitur: 'In monte Dominus videtur'. Vocavit autem angelus Domini Abraham secundo de caelo et dixit:'Per memetipsum iuravi, dicit Dominus: quia fecisti hanc rem et non pepercisti filio tuo unigenito, benedicam tibi et multiplicabo semen tuum sicut stellas caeli et velut arenam, quae est in litore maris. Possidebit semen tuum portas inimicorum suorum, et benedicentur in semine tuo omnes gentes terrae, quia oboedisti voci meae». 
Después de estas cosas sucedió que Dios tentó a Abraham y le dijo: “iAbraham, Abraham!" Él respondió: "Heme aquí". Díjole: “Toma a tu hijo, a tu único, al que amas, a Isaac, vete al país de Moriah y ofrécele allí en holocausto en uno de los montes, el que yo te diga". Levantóse, pues, Abraham de madrugada, aparejó su asno y tomó consigo a dos mozos y a su hijo Isaac. Partió la leña del holocausto y se puso en marcha hacia el lugar que le había dicho Dios. Al tercer día levantó Abraham los ojos y vio el lugar desde lejos. Entonces dijo Abraham a sus mozos: "Quedaos aquí con el asno. Yo y el muchacho iremos hasta allí, haremos adoración y volveremos donde vosotros". Tomó Abraham la leña del holocausto, la cargó sobre su hijo Isaac, tomó en su mano el fuego y el cuchillo, y se fueron los dos juntos. Dijo Isaac a su padre Abraham: “¡Padre!” Respondió: “¿Qué hay, hijo?”. “Aquí está el fuego y la leña, pero ¿dónde está el cordero para el holocausto?”. Dijo Abraham: “Dios proveerá el cordero para el holocausto, hijo mío". Y siguieron andando los dos juntos. Llegados al lugar que le había dicho Dios, construyó allí Abraham el altar, y dispuso la leña; luego ató a Isaac, su hijo, y le puso sobre el ara, encima de la leña. Alargó Abraham la mano y tomó el cuchillo para inmolar a su hijo. Entonces le llamó el Ángel de Yahveh desde los cielos diciendo: “¡Abraham, Abraham!” Él dijo: “Heme aquí”. Dijo el Ángel: "No alargues tu mano contra el niño, ni le hagas nada, que ahora ya sé que tú eres temeroso de Dios, ya que no me has negado tu hijo, tu único". Levantó Abraham los ojos, miró y vio un carnero trabado en un zarzal por los cuernos. Fue Abraham, tomó el carnero, y lo sacrificó en holocausto en lugar de su hijo. Abraham llamó a aquel lugar "Yahveh provee", de donde se dice hoy en día: "En el monte 'Yahveh provee”'. El Ángel de Yahveh llamó a Abraham por segunda vez desde los cielos, y dijo: "Por mí mismo juro, oráculo de Yahveh, que por haber hecho esto, por no haberme negado tu hijo, tu único, yo te colmaré de bendiciones y acrecentaré muchísimo tu descendencia como las estrellas del cielo y como las arenas de la playa, y se adueñará tu descendencia de la puerta de sus enemigos. Por tu descendencia se bendecirán todas las naciones de la tierra, en pago de haber obedecido tú mi voz".

Si bien el pasaje es extenso, la mayor parte de los significados extraídos del mismo han sido principalmente condensados en el momento en el que Abrahán se dispone a ejecutar a Isaac y un ángel emerge de la bóveda celeste para detener su acción. El alto grado de difusión del tema durante el barroco se debió, en buena parte, al dramatismo del suceso, pero, sobre todo, a la exégesis tipológica de la literatura patrística que vio en este holocausto veterotestamentario una prefiguración de la pasión de Cristo.

Espinosa partió a la hora de componer El Sacrificio de Isaac de esquemas compositivos previos que le eran familiares y por los que transitaba de manera cotidiana. Por ello, a la hora de encauzar el análisis de este lienzo hemos de partir del capitel de la puerta de l'Almoina (s.XIII, Catedral de Valencia) [fig. 4] en donde Abrahán ha sido dispuesto con la cabeza volteada hacia el ángel intercesor que desde la bóveda celeste emerge para detener su acción. Junto al patriarca, y sobre lo que semeja una esquemática representación del monte Moria, encontramos a Isaac encima de la leña, previamente cortada para el holocausto y, en primer término, al carnero que habrá de sustituirlo. 


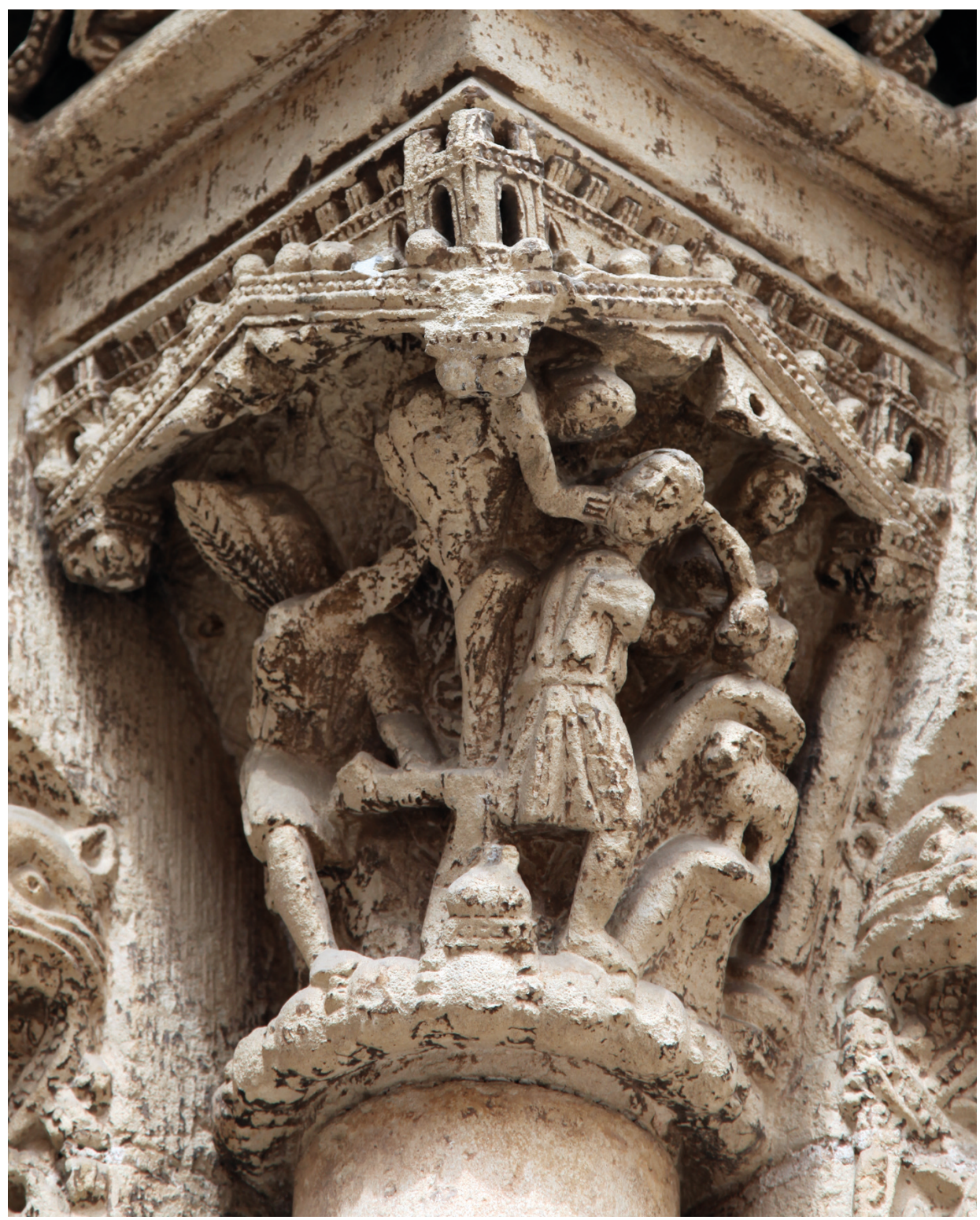

Fig. 4. Capitel de la puerta de l’Almoina, s.XıII, Portada románica de la Catedral de Valencia

De igual modo, y como ya señalaron autores como Delphine Fitz Darby o Fernando Benito, tanto Ribalta como Espinosa empleaban las estampas de grabadores como Cornelis Cort para «confeccionar sus respectivos 
cuadros». ${ }^{18}$ Pudiendo valerse de aguafuertes flamencos como el publicado por Cornelis Galle el Viejo (ca. 1630-1650, Londres, BM, 1891,0414.546) [fig.5] o de esbozos procedentes de Italia como el que se conserva en la Biblioteca Nacional de España (Anónimo italiano, s.XVI, Madrid, BNE) con el mismo tipo iconográfico, ${ }^{19}$ Espinosa llegó a conformar un Sacrificio de Isaac único y, en ocasiones, olvidado dentro de los estudios dedicados a su producción pictórica.

Respecto al ara sacrificial, Espinosa, al igual que de Orrente o Galle, no emplea para su composición un altar labrado o vestido como sí acontece en otras variantes del tipo iconográfico, sino que, conocedor de la prohibición establecida en el libro del Éxodo, opta por que este siga lo estipulado en las Sagradas Escrituras (Ex 20, 24-26): ${ }^{20}$

Hazme un altar de tierra para ofrecer sobre él tus holocaustos y tus sacrificios de comunión, tus ovejas y tus bueyes. En todo lugar donde haga yo memorable mi nombre, vendré a ti y te bendeciré. Y si me haces un altar de piedra, no lo edificarás de piedras labradas; porque al alzar tu cincel sobre ella queda profanada. Tampoco subirás por gradas a mi altar, para que no se descubra tu desnudez sobre él.

No es llamativo, por tanto, que Isaac haya sido dispuesto sobre una pila de troncos junto a unas rocas apiladas y extraídas del propio monte Moria. La localización de este sacrificio tampoco es casual y sobre esta han girado los planteamientos de la exegética barroca. Concretamente, y si acudimos a los comentarios realizados sobre el Antiguo Testamento por el jesuita Cornelio a Lapide, advertimos la relevancia de este lugar sagrado destinado a convertirse en el testigo de los principales misterios del cristianismo. El teólogo flamenco se refería a Moria, apenas veinte años antes de que Espinosa compusiera su lienzo, como el lugar donde se hallaba la tumba de Adán, donde Salomón alzó su templo y donde Cristo fue crucificado, añadiendo que según la tradición hebrea también podría haber sido el lugar que vio el sacrificio de Abel o la ofrenda de Noé. ${ }^{21}$

18. Fernando Benito Doménech: «Jerónimo Jacinto de Espinosa en sus comienzos como pintor», Ars Longa, 4, 1993, pp. 59-63.

19. Este dibujo fue ya recogido en: Ángel M. DE BARCiA: Catálogo de la colección de dibujos originales de la Biblioteca Nacional, Madrid: Tipografía de la revista de Archivos, Bibliotecas y Museos, p. 539.

20. «Altare de terra facietis mihi et offeretis super eo holocausta et pacifica vestra, oves vestras et boves; in omni loco, in quo memoriam fecero nominis mei, veniam ad te et benedicam tibi. Quod si altare lapideum feceris mihi, non aedificabis illud de sectis lapi- dibus; si enim levaveris cultrum super eo, polluetur. Non ascendes per gradus ad altare meum, ne reveletur turpitudo tua».

21. Cornelius Corneli a Lapide: In Pentateuchum Mosis commentaria, París: Edmundi Martini, 1626, p.175. 


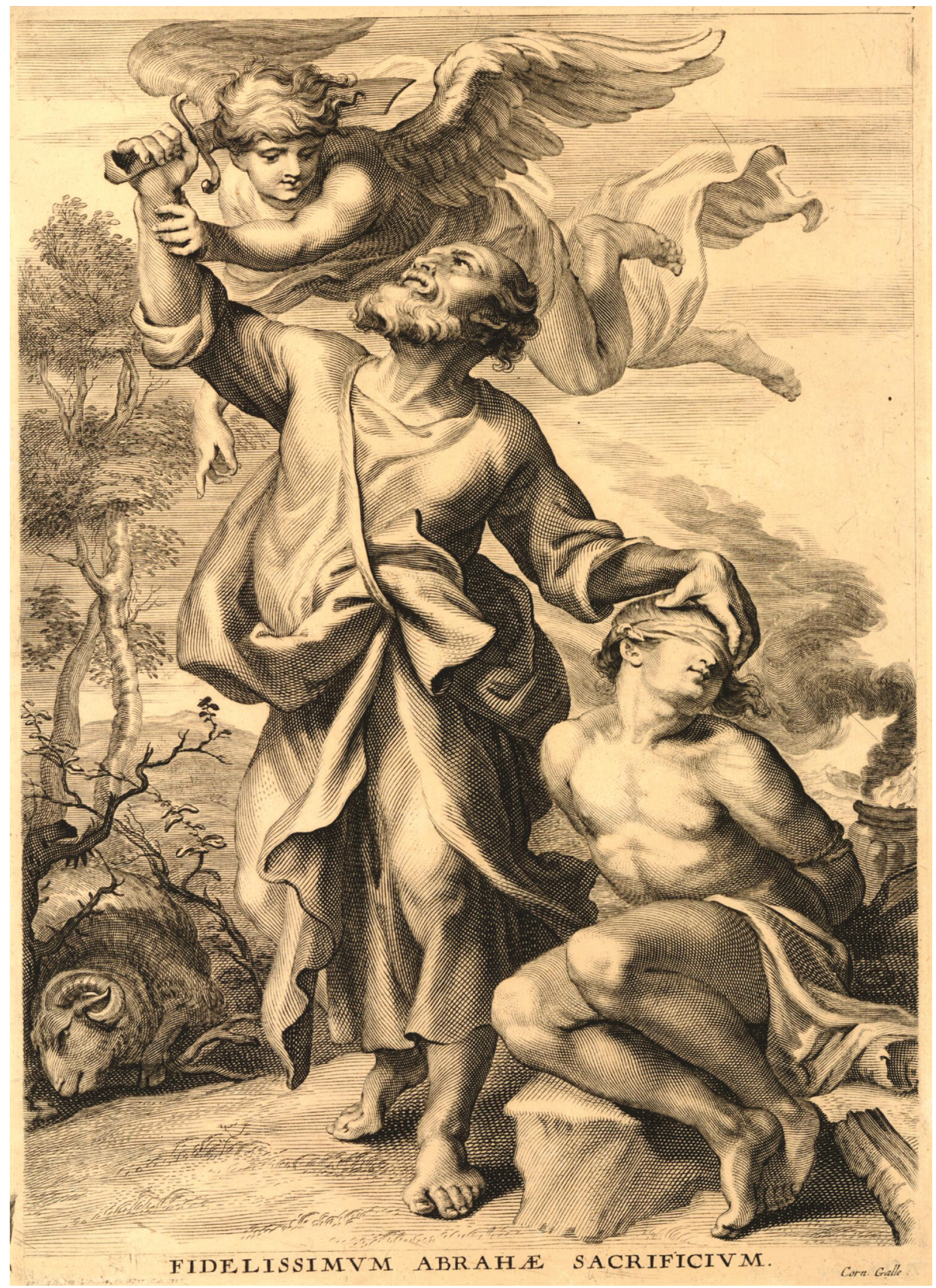

Fig. 5. Cornelis Galle el Viejo, Sacrificio de Isaac, ca.1630, 302 × 213 mm, British Museum,1891,0414.546, Londres 
Isaac ha sido representado cubierto únicamente por una tela que, a modo de paño de pureza, evita la desnudez total del sacrificado siguiendo las prescripciones tridentinas y el principio de decorum, pues tal y como se estableció en Trento las imágenes no habían de ser adornadas «con hermosura escandalosa». ${ }^{22} \mathrm{La}$ controversia generada en torno al desnudo en el arte favoreció el surgimiento y diáspora de numerosos tratados pictóricos centrados en el veto a la desnudez. Libros como Il Dialogo degli errori dei pittori de Giovanni Andrea Gilio (1564) o Il Riposo de Raffaello Borghini (1584) atestiguan esta censura hacia el desnudo en el arte. Desde Molanus hasta el cardenal Paleotti encontramos textos que ponen su mirada en la imagen sacra. Espinosa, fiel a los postulados tridentinos, evita el desnudo total de Isaac sumándose así a la lista de artistas que, como Philippe de Champagne, optaron por no realizar ningún desnudo, haciendo consigo todavía más ardua la labor de pintar con verosimilitud el pasaje veterotestamentario.

Así mismo, la configuración icónica es recogida en El Arte de la Pintura de Francisco Pacheco donde reúne los alegatos de S. Gregorio Niceno quien, al contemplarla, «mudaba interiormente, sin poder detener las compasivas lágrimas», señalando también los Santos Padres la utilidad de la imagen sacra que «si a tan maestro dio lágrimas y utilidad, cuanto más útil será a los hombres rudos» ${ }^{23}$ Este tipo de testimonios advierten como la representación del momento culminante del pasaje veterotestamentario sirvió de apoyo visual para la elevación espiritual y la meditación en torno a los misterios divinos.

Una de las claves interpretativas en lo relativo a la figura de Isaac la hallamos en el versículo noveno del Génesis 22 (Gn 22, 9), ${ }^{24}$ en el cual se especifica que Abraham ató a Isaac: «Llegados al lugar que le había dicho Dios, construyó allí Abraham el altar, y dispuso la leña; luego ató a Isaac, su hijo, y le puso sobre el ara, encima de la leña». La hermenéutica cristiana verá en esta Akedah, término hebraico que significa atadura o ligadura, una lectura tipológica que vincula la figura de Isaac con la de Cristo y, al mismo tiempo, una predisposición por parte del hijo quien es conducido al sacrificio como cordero tal y como postula Melitón de Sardes (Melit. Fr.; PG, V, 12161218). ${ }^{25}$ Además de las ataduras de Isaac, la venda que cubre sus ojos cobra

22. Decreto «Deinvocations, veneration,etreliquiis Sanctorum, etsacrisimaginibus», de El sacrosanto y ecuménico Concilio de Trento, sesión xxv, 4 de diciembre de 1563 . Texto latino publicado en Roma en 1564, traducción al castellano realizado por Ignacio López de AyAla (trad.), El sacrosanto y ecuménico Concilio de Trento, París: Librería de Rosa, 1853, pp. 361-366.

23. Francisco Pacheco: El arte de la pintura, Madrid: Cátedra, 1990, p. 257.

24. «Et venerunt ad locum, quem ostenderat ei Deus, in quo aedificavit Abra- ham altare et desuper ligna composuit. Cumque colligasset Isaac filium suum, posuit eum in altari super struem lignorum».

25. «Sicut Enim Aries vinctus est, inquit de Domino nostro Jesu Christo, et sicut agnus tonsus est, et sicut ovis ad occisionem ductus est, et sicut agnus crucifixus est, et portavit lignum humeris, adductus ut immolaretur, sicut Isaac, a patre suo. Sed Christus passus est, Isaac autem non est passus; typus enim erat futurae passionis Dominicae. Autem licet typus tantum modo Christi esset, tamen stupore et timore percussit homines». 
un papel protagonista dentro de la configuración icónica de esta variante del tipo iconográfico. Al igual que de Orrente, Cano o Valdés Leal y, posiblemente siguiendo el grabado de Cornelis Galle el Viejo, Espinosa dispuso sobre Isaac una venda que cubriera sus ojos y sirviera a Abrahán para aferrarse a la testa de su hijo.

Desde la iconografía, autores como Louis Réau dan fe de la consolidación de esta variante del tipo iconográfico: «la cuarta escena es la del sacrificio propiamente dicho. Las otras, que solo son la preparación, con frecuencia se eliminan. Isaac, con los ojos vendados, como los condenados a muerte antes de la ejecución, se arrodilla frente al altar». ${ }^{26}$ Los planteamientos de Réau siguen la estela de lo ya descrito en 1887 por Joseph Wilpert quien advirtió que la venda podría inspirarse en los relatos de las ejecuciones de los primeros mártires del cristianismo, en las cuales frecuentemente se menciona que sus ojos fueron vendados. ${ }^{27}$ De este modo, la venda que cubre los ojos de Isaac acentúa el dramatismo del momento culminante del pasaje veterotestamentario, encontrando en algunas representaciones como la Grande Bible historiale compléteé (1380-1390, Guiart des Moulins, BNF, Français 20090, fol. 22v) [fig.6] asociaciones directas con las ejecuciones. La presencia de esta venda dentro del Sacrifico de Isaac, aunque ausente en las Sagradas Escrituras, ha sido citada por tratadistas y teólogos como Johannes Molanus quien, en su De historia SS. imaginum et picturarum pro vero earum usu contra abusus libri $I V,^{28}$ ya dispuso que Isaac habría de llevar el rostro cubierto. El jesuita Charles de la Rue, a principios del siglo XVII, en sus Panegyriques, Oraisons funèbres et Sermons de morale describía el momento del sacrificio como la inmolación de Isaac en tanto que víctima inocente que ha sido dispuesta sobre la hoguera por las manos de Abrahán, con los brazos atados y los ojos vendados. ${ }^{29}$ En 1743 el tratadista francés, François Maximilien Misson en su Voyage d'Italie se sorprendía frente a obras que no presentaran lo que él denominaba la manera común de pintar a Isaac en el sacrificio, es decir, genuflexo y con los ojos vendados. ${ }^{30}$ Con todo ello, la consulta de las fuentes, así como la pervivencia de la venda sobre los ojos de Isaac en el arte dan fe de la consolidación de esta variante que, a partir del Barroco, terminará por consolidarse como canónica dentro de la tradición cultural convencionalizada occidental.

26. LouIs RÉAu: Iconografia del arte cristiano. Iconografía de la Biblia-Antiguo Testamento, Barcelona: Ediciones del Serbal, 2007, p. 167.

27. Joseph Wilpert: «Das Opfer Abrahams in der altchristlichen Kunst mit besonderer Berücksichtigung zweier unbekannten Monumente», Römische Quartalschrift, 1, 1887, pp. 126-160.

28. Johanes Molanus: De historia SS. imaginum et picturarum pro vero earum usu contra abusus libri IV, Lovanii: Typis Academicis, 1575, p. 50.

29. «Cet innocent Isaac elevé sur le bûcher par les mains d’Abraham, les bras liés, les yeux bandés, \& sur le Point d'être inmolé, ne songeoit plus à son héritage». Charles DE LA Rue: Panegyriques des Saints, 1740, París: Pierre Gissey, p. 215.

30. «Coûtume de peindre Isaac à genoux et les yeux bandés». François Maximilien Misson: Voyage d'Italie, París: Augmentée, vol. 2, 1743, p. 253. 


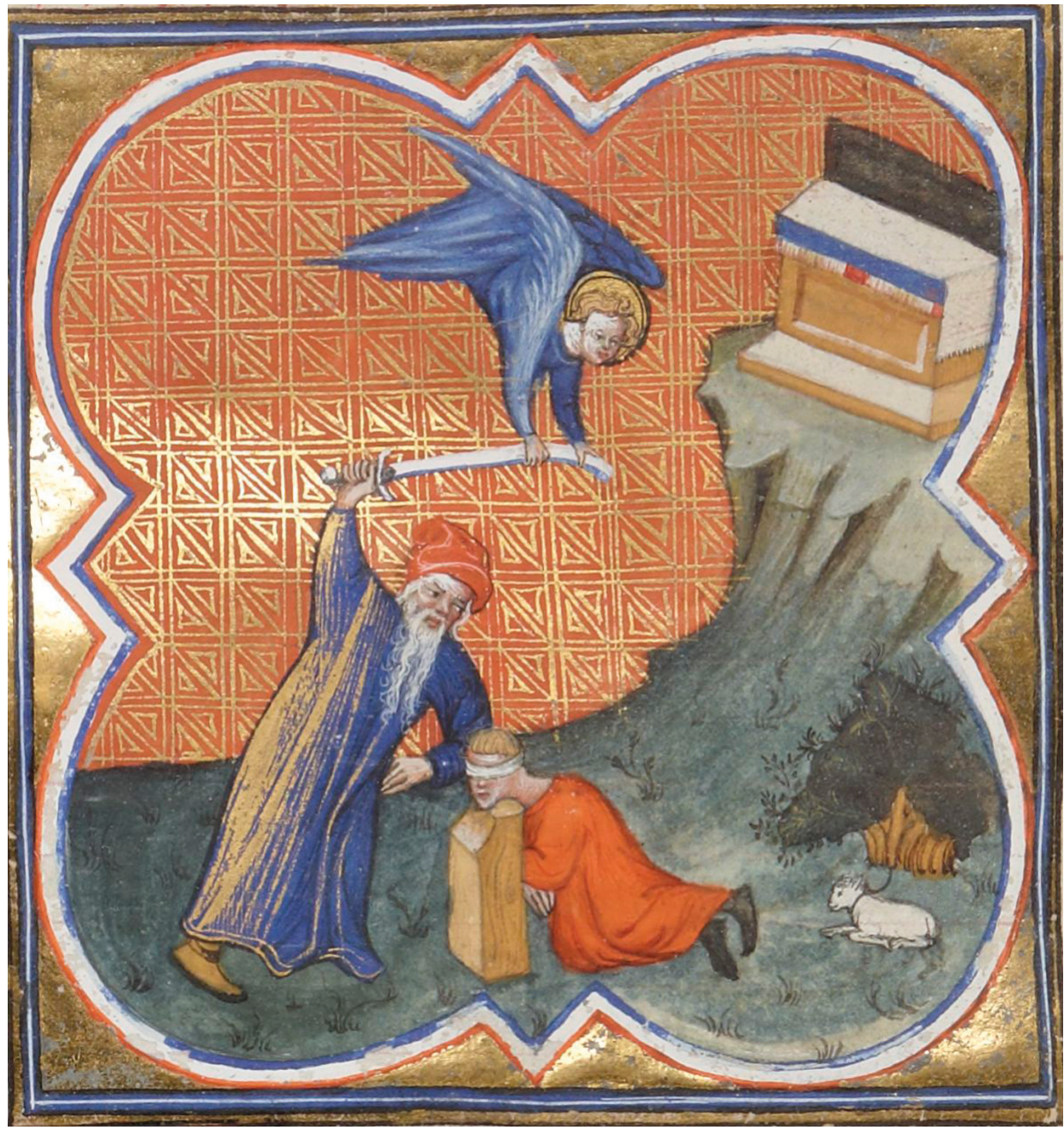

Fig. 6. Guiart des Moulins, Grande Bible historiale complétée, 1380-1390, Biblioteca Nacional de Francia, Français 20090, fol. 22v, París

Más allá de las cualidades expresivas del sacrificio, hemos de acudir a lo descrito en el Antiguo y Nuevo Testamento para hallar el sentido simbólico de la venda que cubre los ojos de Isaac. Por un lado, el velo o venda podría ser empleado a modo de protección frente a lo sobrenatural, estableciendo con ello una separación entre lo divino y lo terreno. Cubrirse el rostro manifestaría, por tanto, una actitud de reserva y distancia con la divinidad, la misma que Moisés presenta cuando se cubre el rostro frente a la zarza 
ardiente «porque temía mirar a Dios» $(E x 3,6),{ }^{31}$ suponiendo esta acción un acto de protección frente a un poder sobrehumano. Del mismo modo, en el Levítico podemos encontrar como Moisés, siguiendo las órdenes de Yahvé, indica a su hermano Aarón que no debe pasar el santuario que se encuentra tras el velo, pues podría morir ( $\operatorname{Lv} 16,2) .{ }^{32}$ Por otro lado, y siguiendo la exégesis bíblica, este podría ser otro elemento más como la leña o la zarza que permita establecer asociaciones entre la figura de Isaac y la de Cristo en tanto que prefigura. Para ello, hemos de acudir a los evangelios de Lucas (Lc 22, 63-65) $)^{33}$ y Marcos (Mc 14,65) $)^{34}$ en donde es descrito el momento en el que son dirigidos los improperios a Cristo, a quien se le vendan los ojos para que adivine cuál de los sayones le propina los golpes.

Por otro lado, Abrahán fue retratado por Espinosa como un hombre vetusto y barbado, tal y como fue concebido dentro de las representaciones del tipo iconográfico desde sus orígenes. En la vestimenta del patriarca hallamos una de las particularidades estilísticas del pintor quien, como advertía Perez Sánchez, gustaba de trasladar los temas sacros al ámbito de lo cotidiano. ${ }^{35}$ Por este motivo, no hallamos en el lienzo un Abrahán ataviado con túnica sacerdotal o engalanado con ropas moriscas sino, más bien, un Abrahán humilde que se aproxima a la realidad del creyente y que le permite acceder al misterio que la obra preserva. En este sentido, el lienzo se inscribe dentro de la llamada pintura reformada que, como ya definió Rafael García Mahíques, «encarna los ideales estéticos surgidos del concilio de Trento». Esta nueva estética trata de armonizar el decorum, es decir lo apropiado para el culto y la devoción, con el naturalismo. La obra según estos parámetros había de ser próxima a la realidad tangible y, al mismo tiempo, dignificar de manera ideal el tema religioso que había de servir para la contemplación. ${ }^{36}$ De este modo, y continuando con la tradición ribaltiana, es en la humildad del patriarca donde descubrimos la capacidad de Espinosa de hallar en lo profano un lugar para lo sacro.

Por lo que respecta al arma sacrificial, Espinosa descarta el alfanje o aljanyar presente en Sacrificios de Isaac contemporáneos, como el realizado

31. «Et ait: 'Ego sum Deus patris tui, Deus Abraham, Deus Isaac et Deus Iacob'. Abscondit Moyses fa-ciem suam; non enim audebat aspicere contra Deum».

32. «Loquere ad Aaron fratrem tuum, ne omni tempore ingrediatur sanctuarium, quod est intra velum coram propitiatorio, quo tegitur arca, ut non moriatur, quia in nube apparebo super propitiatorium».

33. «Et viri, qui tenebant illum, illudebant ei caedentes; et velaverunt eum et interrogabant eum dicentes: "Prophetiza: Quis est, qui te percussit?". Et alia multa blasphemantes dicebant in eum» (Lc 22, 63-65).

34. «Et coeperunt quidam conspuere eum et velare faciem eius et colaphis eum caedere et dicere ei: "Prophetiza "; et ministri alapis eum caedebant».

35. Alfonso E. Pérez SÁnchez: Jerónimo Jacinto de Espinosa (1600-1667), Valencia: Generalitat Valenciana, 2001, p. 44.

36. Rafael García Mahíques: «Contrerreforma y Barroco», en Fernando Benito Doménech (dir.), La luz de las imágenes, Valencia: Generalitat Valenciana, 1999, p.18. 
por Mattia Preti (ca. 1650), considerado un arma de ejecución y más concretamente de decapitación. ${ }^{37} \mathrm{El}$ artista contestano opta por una espada de guarnición conocida en el mundo anglosajón como bilbo y en el ámbito hispano como de guarnición bivalva, de conchas o veneras.

La intervención angélica, así como su manera de interactuar con el patriarca, responde a los cánones de la visualidad barroca en donde la primigenia Dextera Dei ha dejado paso a la visualidad del ángel intercesor. Detrás de Abrahán, la presencia de un joven imberbe de fisonomía adolescente remite directamente a los primeros ángeles configurados por el arte cristiano, aquellos que, según describen las sagradas Escrituras, cobran apariencia humana al interactuar con los mortales. ${ }^{38}$ La voz que clama desde los cielos al patriarca y lo exhorta a detener el sacrificio también fue objeto de exégesis para la literatura patrística que vio en el Ángel de Yahvé la materialización de la propia voz divina tal y como expresa Orígenes (Hom. in Gen. 8, 8; SC 7/ bis, 208-209). ${ }^{39}$ De un modo similar, Pedro el Venerable contempla la manifestación de esta forma angélica con la palabra de Dios que adquiere forma física frente a los ojos del patriarca (Adv. Iuda. 2; PL, 189, 521-522)..$^{40}$ Una vez consolidados los postulados tridentinos, exégetas como Cornelio a Lapide retomaron el estudio de la intervención divina estableciendo que esta se manifiesta a través de un ángel que no ha de ser confundido con el hijo de Dios:

Verum contrarium docent passim Patres, scilicet angelum hunc fuisse angelum, non Filium Dei patet enim ex sequentibus eum loqui ut legatum Dei, verbaque Dei enuntiare, quasi esset praeco Dei, ergo fuit angelus, non Filius Dei. ${ }^{41}$

Señalado por el ángel intercesor, Espinosa dispone, en la esquina inferior izquierda, al carnero que habrá de sustituir a Isaac tras la prueba de fe. Siguiendo lo descrito en las Sagradas Escrituras, el animal elegido para

37. Germán Dueñas Beraiz: «Introducción al estudio tipológico de las espadas españolas: Siglos XVI-XVII», Gladius, 24, 2004, pp. 209-260.

38. Rafael García Mahíques: «Tipologías angélicas generales», en Rafael García Mahíques (dir.), Los Tipos Iconográficos de la Tradición Cristiana. Los Ángeles I. La Gloria y sus jerarquías, Ediciones Encuentro, Madrid, 2016, pp. 108-165.

39. Et tamen considerandum est, quia ángelus haec refertur ad Abraham locutus, et quia in consequentibus evidenter hic ángelus Dominus ostenditur. Unde puto quod sicut inter nos homines habitu repertus est un homo, ita et inter angelos habitu est repertus ut ángelus.

40. Hic enim velut angeli metas excedens, Dei personam sibi assumere videtur, ut ilie, quem Abrahae loquentem eadem Genesis Scriptura introduir, dicens: Ecce angelus Domini de caelo clamavit: Abraham, Abraham (Gen XXII). Et verso interpositio: Nunc cognovi quia times Deum, et non pepercisti filio tuo ungenito proper me. Sed tamen Abraham, non propter angelum, sed propter Deum filio suo non pepercerat. Videtur ergo in his verbis personam Dei eumdem sibi angelum assumpsisse, vel Deum in angelo locuntu fuisse.

41. Corneliun Corneli a Lapide: In Pentateuchum Mosis commentaria, París: Edmundi Martini, 1626, p. 179 
las representaciones del episodio veterotestamentario es el carnero, concretamente el macho domesticado de la especie ovis orientalis aries, pues las cualidades fácticas de su cornamenta permitieron a los Padres de la Iglesia establecer relaciones tipológicas entre este y Cristo. No obstante, en algunos casos concretos y potenciando el valor simbólico de la cornamenta del animal, los artistas han incorporado subespecies silvestres del ovis orientalis como el muflón (Ovis orientalis vignei) o el urial (Ovis orientalis musimon) al tipo iconográfico. ${ }^{42}$ Estas cualidades expresivas ligadas a las diferentes exégesis del texto sacro han derivado en que el animal bíblico se codifique también como cordero, es decir, la cría de la especie domesticada puesta en relación con la figura del Agnus Dei redentor, pudiendo remplazar este animal al carnero como ya advirtió Louis Réau. ${ }^{43}$

Siguiendo el texto sacro, el artista contestano pinta con verosimilitud el elemento vegetal en el que se encuentra atrapado el carnero. La zarza o Rubus fructicosus destaca por sus largos tallos flexibles llenos de espinas, así como por sus hojas pinnadas patentes en el lienzo. Son numerosos los ejemplos en los que podemos encontrar al animal vinculado al zarzal, pues la imagen del carnero atrapado en este elemento vegetal permitió a los primeros exégetas cristianos establecer, de manera temprana, las asociaciones tipológicas anteriormente mencionadas entre los elementos del pasaje veterotestamentario y la Pasión de Cristo. De este modo, la tradición paulina es continuada por Melitón de Sardes o Tertuliano (Tert. Adv.iud. X; PL II, 626) ${ }^{44}$ quienes ahondan en la relación existente entre la madera del holocausto o el zarzal del Génesis 22 y la cruz y la corona de espinas del Nuevo Testamento.

Todas estas asociaciones tipológicas y reflexiones exegéticas son recogidas por los planteamientos contrarreformistas que ven en el holocausto veterotestamentario una prefigura eucarística que facilita la comprensión del sacrifico de Cristo. Estas asociaciones pervivieron en el imaginario barroco como evidencia la exégesis realizada por Fray Juan de Mora en su Enigma numérico predicable, encontrando entre sus páginas referencias dirigidas al animal sustitutorio:

«Y el Sacramento Eucharistico figurado en el Cordero, que viò Abrahan entre espinas» como al arma sacrificial: «Isaac, rindiendo el cuello al imperioso golpe del cuchillo del qual, como afirma el doctisimo Isaac Hebreo, se formaron

42. Andrés Herraiz Llavador: «El ángel y el carnero en el Sacrificio de Isaac. Continuidad y variación en la cultura visual», Boletín de Arte-UMA, 41, Málaga: Universidad de Málaga, 2020, pp. 93102.

43. LouIs RÉAu: Iconografia del arte cristiano. Iconografía de la Biblia-Antiguo Testamento, Barcelona: Ediciones del Serbal, 2007, p. 167.

44. «Itaque imprimis Isaac, cum a patre hostia duceretur lignum [que] ipse sibi portans, Christi exitum iam tunc denotabat in victimam concessi a patre lignum passionis suae baiulantis». 
después los clavos, con que fue enclavado Christo mi bien en la Cruz $[\ldots]^{45}$

De este modo, el Sacrificio de Isaac de Espinosa se erige como modelo del arte religioso contrarreformista, un arte severo, sintético, en el que nada es accesorio o distrae al fiel de su meditación, sino que lo refuerza en su fe. Siguiendo lo ya estudiado por Émile Mâle, todo aquello que no sirva a este fin debe ser alejado ya que es la grandeza del Evangelio lo que debe emocionarnos, no la belleza de la naturaleza o su mimesis. ${ }^{46}$ Así, la doctrina de la Iglesia halló en Abrahán un ejemplo que facilitaba el acercamiento del fiel al culto eucarístico y, al mismo tiempo, que sirviera como modelo de obediencia y sumisión al mandato divino. La Iglesia Católica se encontraba en este momento en una pugna constante frente al terror escatológico generado por los piratas berberiscos y la inestabilidad del pontificado, por ello requería de modelos que reforzaran la fe del creyente en las promesas divinas y aliviaran así el horror de la visión de la muerte, no tanto del cuerpo sino del alma. Centrándose en el aspecto salvífico de las buenas obras, el concilio de Trento, en su primera etapa, declaró que la fe tiene una parte importante en la justificación, pero que esta no se realiza solamente por la fe. La justificación consistía en la misma justicia de Dios, que nos hace justos a los hombres y que, además, requiere la colaboración del individuo a la acción divina de la gracia mediante las buenas obras. ${ }^{47}$ Inserta en esta línea interpretativa, la primera epístola de Santiago (St. 2, 12-24) ${ }^{48}$ exalta la fe de Abrahán como modelo de justificación por las obras:

Hablad y obrad tal como corresponde a los que han de ser juzgados por la Ley de la libertad. Porque tendrá un juicio sin misericordia el que no tuvo misericordia; pero la misericordia se siente superior al juicio. ¿De qué sirve, hermanos míos, que alguien diga: “¿Tengo fe”, si no tiene obras? ¿Acaso podrá

45. Juan De Mora: Enigma numérico predicable, Madrid: Imprenta de Juan García Infançon, 1628, p. 183.

46. Émile MÂle: El Barroco. Arte religioso del siglo XVII. Italia, Francia, España, Flandes, Ana Ma GuASCH (trad), Madrid: Encuentro, 1985, p. 29.

47. Rafael Benítez SÁnchez-Blanco: «La Contrarreforma», en Miguel Navarro Sorní (dir.) La luz de las imágenes, Valencia: Generalitat Valenciana, 1999, p. 222.

48. Sic loquimini et sic facite sicut per legem libertatis iudicandi. Iudicium enim sine misericordia illi, qui non fecit misericordiam; superexsultat misericordia iudicio. Quid proderit, fratres mei, si fidem quis dicat se habere, opera autem non habeat? Numquid poterit fides salvare eum? Si frater aut soror nudi sunt et indigent victu cotidiano, dicat autem aliquis de vobis illis: "Ite in pace, calefacimini et saturamini", non dederitis autem eis, quae necessaria sunt corporis, quid proderit? Sic et fides, si non habeat opera, mortua est in semetipsa. Sed dicet quis: "Tu fidem habes, et ego opera habeo". Ostende mihi fidem tuam sine operibus, et ego tibi ostendam ex operibus meis fidem. Tu credis quoniam unus est Deus? Bene facis; et daemones credunt et contremiscunt! Vis autem scire, o homo inanis, quoniam fides sine operibus otiosa est? Abraham, pater noster, nonne ex operibus iustificatus est offerens Isaac filium suum super altare? Vides quoniam fides cooperabatur operibus illius, et ex operibus fides consummate est; et suppleta est Scriptura dicens: “Credidit Abraham Deo, et reputatum est illi ad iustitiam", et amicus Dei appellatus est. Videtis quoniam ex operibus iustificatur homo et non ex fide tantum. 
salvarle la fe? (...) Así también la fe, si no tiene obras, está realmente muerta. Y, al contrario, alguno podrá decir: “¿Tú tienes fe?; pues yo tengo obras. Pruébame tu fe sin obras y yo te probaré por las obras mi fe. ¿Tú crees que hay un solo Dios? Haces bien. También los demonios lo creen y tiemblan ¿Quieres saber tú, insensato, que la fe sin obras es estéril? Abraham nuestro padre ¿no alcanzó la justificación por las obras cuando ofreció a su hijo Isaac sobre el altar? ¿Ves cómo la fe cooperaba con sus obras y, por las obras, la fe alcanzó su perfección? Y alcanzó pleno cumplimiento la Escritura que dice: Creyó Abraham en Dios y le fue reputado como justicia y fue llamado amigo de Dios". Ya veis cómo el hombre es justificado por las obras y no por la fe solamente.

De este modo, y a través de la prueba de fe a la que Dios somete a Abrahán, se promulgaba la idea de que el hombre no se justifica solamente por su fe sino por sus obras. La iglesia valenciana imbuida por el espíritu reformista y, capitaneada por la figura del Patriarca Ribera, promovió la fundación de colegios en los que se formara a los prelados, en ocasiones desconocedores de la lengua propia de las Sagradas Escrituras. El paradigma de este proceso paulatino es el Colegio del Corpus Christi de Valencia en cuya capilla de la Inmaculada el tipo iconográfico de Abraham alzando el cuchillo para sacrificar a Isaac (ca. 1606, Valencia, Colegio del Corpus Christi, Capilla de la Purísima) se inscribe, junto a otras prefiguras veterotestamentarias, dentro del programa iconográfico eucarístico concebido por Juan de Ribera y perpetrado por Tomás Hernández. El episodio bíblico se incluye junto con otros sacrificios expiatorios como «el sacerdocio de Aarón», «el maná», «el cordero pascual»o «el árbol de la vida» dentro de aquello que Alejos Morán definió como «símbolos eucarísticos» ${ }^{49}$ que, en tanto que prefiguras, aventuraban el sacrificio de Cristo. Inserto dentro de los pasajes veterotestamentarios que prefiguran la venida y pasión de Cristo, el episodio de Abrahán y Melquisedec (Gn 14, 17-24) $)^{50}$ ha sido objeto de exégesis por parte de la literatura patrística, que siguiendo la tradición paulina veía en Melquisedec un tipo de Cristo. ${ }^{51}$ Será san Agustín quien en su De civitate Dei relacione este

49. Asunción Alejos Morán: La Eucaristía en el arte valenciano, Valencia: Artes gráficas Soler, 1977, p. 347.

50. A su regreso después de batir a Quedorlaomer y a los reyes que con él estaban, le salió al encuentro el rey de Sodoma en el Valle de Savé (o sea, el Valle del Rey). Entonces Melquisedec, rey de Salem, presentó pan y vino, pues era sacerdote del Dios Altísimo, y le bendijo así: «iBendito sea Abrán del Dios Altísimo, creador de cielos y tierra, y bendito sea el Dios Altísimo, que entregó a tus enemigos en tus manos!» Y Abrán le dio el diezmo de todo. Dijo luego el rey de Sodoma a Abrán: «Dame las personas y quédate con la hacienda». Pero Abrán dijo al rey de Sodoma: «Alzo mi mano ante el Dios Altísimo, creador de cielos y tierra: ni un hilo, ni la correa de un zapato, ni nada de lo tuyo tomaré. Así no dirás que me has enriquecido. Nada en absoluto, salvo lo que han comido los mozos y la parte de los hombres que fueron conmigo: Aner, Escol y Mambré. Ellos que tomen su parte».

51. Este Melquisedec, rey de Salem, sacerdote del Dios Altísimo, que salió al encuentro de Abrahán cuando regresaba de la derrota de los reyes, y le bendijo, es aquel a quien dio Abrahán el diezmo de todo. Su nombre significa, en primer lugar, «rey de justicia»y, además, rey de Salem, es decir, «rey de paz». 
momento junto con el sacerdocio de Aarón con el sacrificio eucarístico (Avg. civ.17, V; PL, 41, 535-536). ${ }^{2}$

El culto eucarístico fue tan relevante que la Sagrada Forma no fue solamente venerada en el tabernáculo del altar, sino que desde las grandes basílicas como Santa María sopra Minerva en Roma hasta las pequeñas sedes como la antigua Parroquia de San Andrés de Valencia contaron con espacios dedicados al culto del Sagrado Sacramento, espacios que florecieron durante los siglos XVI y XVII en el ámbito valenciano. Por ello, no es de extrañar que los lienzos del Sacrificio de Isaac y Abraham y Melquisedec formaran parte de un programa iconográfico centrado en el culto eucarístico. Dado que la antigua parroquia de San Andrés se hallaba en plena remodelación cuando ambas obras fueron pintadas, es lógico suponer que estas formaran parte de un programa iconográfico dedicado a la eucaristía que, con su traslado a la nueva sede en calle Colón, fueran dispuestas flanqueando el altar manteniendo así su función original. Ambas sirvieron de apoyo visual al discurso retórico del párroco quien, ya introducido en el dogma contrarreformista, actuaba de intermediario entre los misterios y el vulgo.

A modo de síntesis, este estudio de caso permite subsanar la deuda que la historia del arte ha tenido con la emblemática obra del artista contestano, advirtiendo el análisis pormenorizado y comparativo de los elementos del lienzo, puestos en relación con las fuentes escritas contemporáneas, la estrecha relación entre la producción pictórica de Espinosa con los planteamientos tridentinos. La violencia y el dramatismo, propios de la visualidad barroca, quedan codificados dentro del tipo iconográfico y se manifiestan a través de la gestualidad con la que Abrahán se aferra a Isaac, así como en la venda que cubre sus ojos. Estos, junto con otros elementos presentes en el lienzo, como el carnero, el zarzal o el altar, atestiguan la vigencia de los planteamientos de los primeros Padres de la Iglesia, así como la confluencia de una serie de exégesis centradas en la asociación entre Isaac y Cristo en tanto

Nada se dice de su padre, su madre o su genealogía; tampoco de su nacimiento y de su muerte. De este modo, a semejanza del Hijo de Dios, permanece sacerdote para siempre ( $\mathrm{Hb} 7,1-3)$.

52. «Quid ergo dicit iste, qui venit adorare sacerdoti Dei et sacerdoti Deo? Jacta me in unam partem sacerdotii tui, manducare panem. Nolo in patrum meorum collocari honore, qui nullus est: jacta me in partem sacerdotii tui. Elegi enim abjectus esse in domo Dei (Psal. LxxxiII, 11): qualecumque et quantulumcumque membrum esse cupio sacerdotii tui. Sacerdotium quippe hic ipsam plebem dicit, cujus plebis ille sacerdos est Mediator Dei et hominum homo Christus Jesus. Cui plebi dicit apostolus Petrus, Plebs sancta, regale sacerdotium (I Petr. II, 9). Quamvis nonnulli, sacrificii tui sint interpretati; non, sacerdotii tui: quod nihilominus eumdem significat populum christianum. Unde dicit apostolus Paulus, Unus panis, unum corpus multi sumus (I Cor. X, 17). Quod ergo addidit, manducare panem, etiam ipsum sacrificii genus eleganter expressit, de quo dicit sacerdos ipse, Panis quem ego dedero, caro mea est pro saeculi vita (Joan. VI, 52). Ipsum est sacrificium, non secundum ordinem Aaron, sed secundum ordinem Melchisedech: qui legit, intelligat. Brevis itaque ista confessio et salubriter humilis, qua dicitur, Jacta me in partem sacerdotii tui, manducare panem, ipse est obolus argenti; quia et breve est, et eloquium Domini est habitantis in corde credentis. Quia enim dixerat superius dedisse se domui Aaron cibos de victimis veteris Testamenti, ubi ait, Dedi domui patris tui omnia quae sunt ignis filiorum Israel in escam; haec quippe fuerant sacrificia Judaeorum: ideo hic dixit, manducare panem; quod est in novo Testamento sacrificium Christianorum». 
que prefigura eucarística. Valiéndonos de la iconografía y la iconología como disciplinas, la obra, a modo de fuente icónica, nos ha permitido aproximarnos a una realidad más amplia en la que fue concebida, un contexto convulso en el que la imagen se hallaba supeditada al juicio y a la reflexión constante. Por tanto, podemos concluir que aquello descrito en el Génesis 22 permitió a Espinosa componer, desde su particular concepción de lo sacro, una obra única que descubre aquello velado tornándolo trascendente y convirtiendo lo narrado en eterno.

\section{BIBLIOGRAFÍA}

A Lapide, Cornelin: In Pentateuchum Mosis commentaria, París: Edmundi Martini, 1626.

Benítez Sánchez-Blanco, Rafael: «La Contrerreforma», en Miguel Navarro Sorní (dir.), La luz de las imágenes, Valencia: Generalitat Valenciana, 1999, p.222.

Benito D., Fernando: Los Ribalta y la pintura valenciana de su tiempo, Valencia: Ayuntamiento de Valencia, 1987.

Benito D., Fernando: «La pintura durant els segles XVI i XVII», en EnrIQue A. Llobregat i José Francisco Ivars (dir.), Història de l'Art al país valencià, Valencia, Biblioteca d'estudis i investigacions Tres i Quatre, 1988.

-: «Jerónimo Jacinto de Espinosa en sus comienzos como pintor», Ars Longa, 1993.

-: Real Colegio y Museo del Patriarca, Valencia: Generalitat Valenciana, 1995.

Beraiz Dueñas, Germán: «Introducción al estudio tipológico de las espadas españolas: Siglos XVI-XVII», Gladius, Madrid, xxIV, 2004.

Bosch Moreno, Victoria: «Jerónimo Jacinto de Espinosa, Concepción Niña», en Pablo González Tornell (ed): Intacta María. Política de religiosidad en la España barroca, Generalitat Valenciana, Valencia, 2020.

Callado Estela, Emilio: El Cabildo de la Catedral de Valencia en el siglo XVII. Crisis y conflicto, Valencia: Tirant humanidades, 2019.

De Barcia, Ángel María: Catálogo de la colección de dibujos originales de la Biblioteca Nacional, Madrid: Tipografía de la revista de Archivos, Bibliotecas y Museos.

De Mora, Juan: Enigma numérico predicable, Madrid: Imprenta de Juan García Infançon, 1628.

De Orellana, Marcos A.: Biografía pictórica Valentina, Xavier de SALAS (ed.) Valencia: Ayuntamiento de Valencia, 1967. 
Espinós Díaz, Adela: Dibuixos Valencians del segle XVII, Valencia: Conselleria de Cultura, 1994.

García MAhíques, Rafael: «Jerónimo Jacinto de Espinosa y la iconografía de San Ignacio de Loyola en la Casa Profesa de Valencia», Archivo español de Arte, 68, 1995.

-: «Contrarreforma y Barroco», en Fernando Benito Doménech (dir.), La luz de las imágenes, Valencia: Generalitat Valenciana, 1999.

-: Iconografía e Iconología. Cuestiones de método, Madrid: Ediciones Encuentro, 2009.

-: Los Tipos Iconográficos de la Tradición Cristiana. La visualidad del Logos, Madrid: Ediciones Encuentro, 2016.

-: «Tipologías angélicas generales», en Rafael García Mahíques (dir.), Los Tipos Iconográficos de la Tradición Cristiana. Los Ángeles I. La Gloria y sus jerarquías, Ediciones Encuentro, Madrid, 2016.

Gimilio Sanz, David: «Jerónimo Jacinto de Espinosa (1600-1667), un pintor valenciano en el Siglo de Oro español», en PABLo GonzÁlez TorneL (ed.): La Inmaculada Concepción de Valencia (1662). Conocer el pasado, recuperar la memoria, Gijón: Ediciones Trea, 2020.

Herraiz Llavador, ANDrés: «Abraham como héroe cristiano. A propósito del lienzo "El sacrificio de Isaac" de Espinosa», en María DE los Ángeles Fernández Valle (ed. lit.), Carme lópez Calderón (ed. lit.), Inmaculada Rodríguez Moya (ed. lit.), Discursos e imágenes del barroco iberoamericano, 2019, Sevilla: Andavira, 2019.

-: «El ángel y el carnero en el Sacrificio de Isaac. Continuidad y variación en la cultura visual», Boletín de Arte-UMA, nº 41, Málaga: Universidad de Málaga, 2020.

Jones D. W., Martin: The Counter Reformation. Religion and Society in Early Modern Europe, Cambridge: Cambridge University Press, 1995.

López De Ayala, Ignacio (trad.): El sacrosanto y ecuménico Concilio de Trento, París: Librería de Rosa, 1853.

MÂle, Émile: El Barroco. Arte religioso del siglo XVII. Italia, Francia, España, Flandes, ANA Ma GuASCH (trad.), Madrid: Encuentro, 1985.

Molanus, Johanes: De historia SS. imaginum et picturarum pro vero earum usu contra abusus libri IV, Lovanii: Typis Academicis, 1575.

Morán Alejos, Asunción: La Eucaristía en el arte valenciano, Valencia: Artes gráficas Soler, 1977.

Pacheco, Francisco: Arte de la pintura, Madrid: Cátedra, 1990.

Palomino De Castro y Antonio Velasco: El Museo Pictórico, Madrid: Aguilar, 1947.

Pérez SÁnchez, Alfonso E.: Jerónimo Jacinto de Espinosa, Madrid: Instituto Diego Velázquez, 1947.

-.: Jerónimo Jacinto de Espinosa (1600-1667), Valencia: Generalitat Valenciana, 2001. 
Pingarrón-Esaín Seco, Fernando: Arquitectura Religiosa del siglo xVII en la ciudad de Valencia, Valencia: Ayuntamiento de Valencia, 1998.

RÉAU, LouIs: Iconografia del arte cristiano. Iconografía de la Biblia-Antiguo Testamento, Barcelona: Ediciones del Serbal, 2007.

Rodríguez Merino, Marcelo: La Biblia comentada por los Padres de la Iglesia y otros autores de la época patrística. Antiguo Testamento, Madrid: Ciudad Nueva, 2005.

Sanchis y Sivera, José: La Catedral de Valencia. Guía histórica y artística, India: Pranava Books, 1908.

Sebastián, Santiago: Contrarreforma y barroco, Madrid: Alianza Editorial, 1981.

Tramoyeres Blasco, Luis: «Un Colegio de Pintores en Valencia», Archivo de Investigaciones Históricas, I, 1911.

-: «El pintor Jerónimo Jacinto de Espinosa», Archivo de Arte Valenciano, 1915.

WiLPERT, JosePH: «Das Opfer Abrahams in der altchristlichen Kunst mit besonderer Berücksichtigung zweier unbekannten Monumente», Römische Quartalschrift, vol. 1, 1887. 